\title{
Determining velocities in high frequency electromagnetic prospecting by phase shift plus interpolation migration
}

- Nguyen Thanh Van

- Le Hoang Kim

- Dang Hoai Trung

- Nguyen Van Thuan

University of Science, VNU-HCM

(Received on July $12^{\text {th }} 2015$, accepted on March $28^{\text {th }} 2016$ )

\begin{abstract}
Phase Shift Plus Interpolation (PSPI) Migration is one of the most popular migration methods that is used not only in Seismic Data Processing but also in interpreting high frequency electromagnetic prospecting [Ground Penetrating Radar (GPR) data]. Based on the similarities between the principle of the propagation of electromagnetic wave and the mechanical wave, migration methods could be applied to interpreting GPR data as a particular step to calculate the medium's velocity, estimate the depth, shape and size of buried objects. Noticeably, there are two kinds of velocities usually used in migration methods: root mean square (RMS) velocity,
\end{abstract}

which is used in $F-K$, Finite Difference and Kirchhoff Migration, and interval velocity, which is used in PSPI Migration. RMS velocity is the average velocity taken into account by considering the influence of the upper layer's instantaneous velocity; whereas the interval velocity only reflect the practical velocity of one layer. In this paper, the problem of how to apply PSPI Migration to interpret GPR data will be presented. Some results of model datum and real datum were also examined. Besides, we made a comparison of using RMS velocity and interval velocity, and then explain how these two types of velocity could be combined to receive the best result.

Keywords: Ground penetrating radar, PSPI Migration, RMS velocity, interval velocity

\section{INTRODUCTION}

Ground Penetrating Radar (GPR) is the geophysical method, which uses electromagnetic wave (typically in the frequency range of 10 to 2000 $\mathrm{MHz}$ ) [1] to study the structure of the shallow subsurface. Meanwhile, Reflection Seismic Exploration is the geophysical methods, which bases on the propagation of the mechanical wave to image subsurface structures and to obtains rock and soil's properties.

Generally, there are three main stages in reflection seismic procedure: Acquisition, data processing analysis, and interpretation. Although the data processing and analysis stage take much time in many different and complicated minor steps, migration is still the most difficult and important step, of which purpose is to transform measured wave fields into images of geological structures in geophysical viewpoin. In recent years, based on the similarities between the principle of the propagation of electromagnetic wave and the mechanical wave (the operators and the variables of two wave equations), migration methods have been studied noticeably to apply to interpreting GPR data. Among those methods, the Phase Shift Plus Interpolation Migration (PSPI migration), which relates to the downward continuation method, being firstly published in 1984 in Geophysics by Jeno Gazdag and 
Piero Squazzero [2], is one of interesting methods in the world but not yet commonly used in Vietnam.

Because PSPI is a kind of depth migration method, the interval velocity is in valid to be used. Unfortunately, in practice, we absolutely do not know exactly the layer structure of the subsurface, so we have to use root mean square (RMS) velocity, which is easier to predict but does not reflect the practical velocity of one layer, instead of interval velocity in migration algorithm. However, thanks to priori information and results of migration step with RMS velocity, the layer structure could be interpreted and the interval velocity of each layer could be calculated through the relevant formula.

\section{METHODS}

\section{Phase shift plus interpolation migration (PSPI)}

Actually, the velocity field of the rock environment is very complex. It is not homogeneous but varies in all directions. However, this variation can be considered in two main directions: in depth and horizontal. The variation of velocity can greatly affect the reflected wave field. The more complicated the velocity field is, the more difficult seismic migration is.

The phase shift plus interpolation migration (PSPI) is one of methods that approach the problem by considering the variation of velocity. Its idea is that the migration problem is separated into two algorithms corresponding to the two main steps:

Step 1: Extrapolate the wave field in depth by the phase shift method in frequency-wave number domain; only consider the depth variable velocity.

Step 2: interpolate each point in horizontal direction to solve the problem of lateral velocity variations. In this step, the conference velocities computed form the interval velocity field would be used to change the wave field in step one to the real wave field.

Assuming that the input data in the domain $(\mathrm{x}, \mathrm{t})$ satisfy the following scalar wave equation

$$
\frac{\partial^{2} \mathrm{P}}{\partial \mathrm{z}^{2}}=\frac{1}{\mathrm{v}^{2}} \frac{\partial^{2} \mathrm{P}}{\partial \mathrm{t}^{2}}-\frac{\partial^{2} \mathrm{P}}{\partial \mathrm{x}^{2}}
$$

Where $\mathrm{P} \rightarrow \mathrm{P}(\mathrm{x}, \mathrm{z}, \mathrm{t})$ is the wave function, $\mathrm{x}$ is the midpoint variable, $\mathrm{z}$ is the depth, $\mathrm{t}$ is two-way traveltime, $\mathrm{v}$ is the half - way velocity. Assuming that the velocity changes only in depth $\mathrm{v}=\mathrm{v}(\mathrm{z})$, perform 2D Fourier transform in both sides of equation (1) and then reduces it, the expression is yielded as:

$$
\begin{aligned}
& \frac{\partial^{2}}{\partial \mathrm{z}^{2}} \mathrm{P}\left(\mathrm{k}_{\mathrm{x}}, \mathrm{z}, \omega\right)=\frac{(\mathrm{i} \omega)^{2}}{\mathrm{v}^{2}} \mathrm{P}\left(\mathrm{k}_{\mathrm{x}}, \mathrm{z}, \omega\right)-\left(\mathrm{ik}_{\mathrm{x}}\right)^{2} \mathrm{P}\left(\mathrm{k}_{\mathrm{x}}, \mathrm{z}, \omega\right) \\
& \Leftrightarrow \frac{\partial^{2} \mathrm{P}\left(\mathrm{k}_{\mathrm{x}}, \mathrm{z}, \omega\right)}{\partial \mathrm{z}^{2}}=\left[\mathrm{k}_{\mathrm{x}}^{2}-\frac{\omega^{2}}{\mathrm{v}^{2}(\mathrm{x}, \mathrm{z})}\right] \mathrm{P}\left(\mathrm{k}_{\mathrm{x}}, \mathrm{z}, \omega\right)
\end{aligned}
$$

Where $\mathrm{kx}$ is the wave number responding to mid point $\mathrm{x}, \omega$ is the radian frequency.

$\mathrm{k}_{\mathrm{z}}$ can be expressed as:

$$
\mathrm{k}_{\mathrm{z}}= \pm\left[\frac{\omega^{2}}{\mathrm{v}^{2}}-\mathrm{k}_{\mathrm{x}}^{2}\right]^{\frac{1}{2}}= \pm \frac{\omega}{\mathrm{v}}\left[1-\left(\frac{\mathrm{vk}_{\mathrm{x}}}{\omega}\right)^{2}\right]^{1 / 2}
$$

Equation (3) becomes:

$$
\frac{\partial^{2} \mathrm{P}}{\partial \mathrm{z}^{2}}=-\mathrm{k}_{\mathrm{z}}^{2} \mathrm{P}
$$

If $\mathrm{v}$ is constant, $\mathrm{kz}$ is also constant, then the equation (5) can be solved as a second-order differential equation with constant coefficients, the analytic solution is:

$$
\mathrm{P}\left(\mathrm{k}_{\mathrm{X}}, \mathrm{z}+\Delta \mathrm{z}, \omega\right)=\mathrm{P}\left(\mathrm{k}_{\mathrm{X}}, \mathrm{z}, \omega\right) \exp \left(\mathrm{ik}_{\mathrm{Z}} \Delta \mathrm{z}\right)
$$

This solution is true when $\mathrm{v}$ varies respectively to $\mathrm{z}$, as long as $\Delta \mathrm{z}$ is small enough [2]. $\Delta \mathrm{z}$ is the phase shift component. In a downward extrapolation process, when $\Delta z$ in equation (6) is positive, sign agreement between $\mathrm{k}_{\mathrm{z}}$ and $\omega$ corresponds to waves that move in the negative $\mathrm{t}$ direction. On the other hand, when $\mathrm{k}_{\mathrm{z}}$ and $\omega$ have opposite signs, equation (6) represents waves that move in the positive $t$ direction [1]. 
Since the downward extrapolation requires $\Delta z>$ 0 , equation (4) has the positive sign. Substituting equation (4) into equation (6), to afford (7)

$\mathrm{P}\left(\mathrm{k}_{\mathrm{X}}, \mathrm{z}+\Delta, \omega\right)=\mathrm{P}\left(\mathrm{k}_{\mathrm{X}}, \mathrm{z}, \omega\right) \exp \left\{\frac{\mathrm{i} \omega}{\mathrm{v}}\left[1-\left(\frac{\mathrm{k}_{\mathrm{X}} \mathrm{v}}{\omega}\right)^{2}\right]^{\frac{1}{2}} \Delta \mathrm{z}\right\}(7)$

Formula (7) is the wave field extrapolation equation. Thanks to this formula, the wave field at any level of depth can be computed from the wave field at a particular level of depth.

The extrapolation equation (7) is not valid for the velocity field with lateral variation [1]. To consider this variation in practice, the general extrapolation equation (6) is firstly splitted into two components:

$$
\begin{gathered}
\mathrm{P}^{*}(\mathrm{z})=\mathrm{P}(\mathrm{z}) \exp \left(\mathrm{i} \frac{\omega}{\mathrm{v}} \Delta \mathrm{z}\right) \\
\mathrm{P}(\mathrm{z}+\Delta \mathrm{z})=\mathrm{P}^{*}(\mathrm{z}) \exp \left[\mathrm{i}\left(\mathrm{k}_{\mathrm{z}}-\frac{\omega}{\mathrm{v}^{\prime}}\right) \Delta \mathrm{z}\right]
\end{gathered}
$$

Where $\mathrm{v}^{\prime} \neq \mathrm{v}(\mathrm{x}, \mathrm{z})$ is an approximation to $\mathrm{v}(\mathrm{x}, \mathrm{z})$.

Equation (8) is a time shift applied to each trace, with $\mathrm{v}=\mathrm{v}(\mathrm{x}, \mathrm{z})$.

Equation (9) can not be calculated directly when v' = $\mathrm{v}(\mathrm{x}, \mathrm{z})$. Its implementation is approximated in two main steps:

Step 1: Find the two velocities $v_{j}$ and $v_{j+1}$ as the extrema of $\mathrm{v}(\mathrm{x}, \mathrm{z})$. These velocities are called reference velocities.

$$
\begin{aligned}
& v_{j}(z)=\operatorname{Min}[v(x, z)] \\
& v_{j+1}(z)=\operatorname{Max}[v(x, z)] \\
& v_{j}>v(x, z)>v_{j+1}
\end{aligned}
$$

Step 2: Substitute those two velocities into equation (9), the two reference wave function can be yielded in frequency-wave number domain, then use the inverse Fourier transformation to bring the wave function back to the domain $(\mathrm{x}, \omega)$.

$$
\begin{aligned}
& P_{j}(x, z+\Delta z, \omega)=\int_{-\infty}^{\infty} P\left(k_{x}, z, \omega\right) \alpha_{j}\left(k_{x}, \omega\right) \exp \left(i_{x} x\right) d k_{x} \\
& P_{j+1}(x, z+\Delta z, \omega)=\int_{-\infty}^{\infty} P\left(k_{x}, z, \omega\right) \alpha_{j+1}\left(k_{x}, \omega\right) \exp \left(i_{x} x\right) d_{x}
\end{aligned}
$$

$$
\alpha_{j}\left(k_{x}, \omega\right)=\left\{\begin{array}{c}
\exp \left(i \Delta \mathrm{zk}_{\mathrm{zj}}\right),\left|\mathrm{k}_{\mathrm{X}}\right| \leq \frac{\omega}{\mathrm{v}_{\mathrm{j}}} \\
\exp \left(-\left|\Delta \mathrm{zk}_{\mathrm{zj}}\right|\right),\left|\mathrm{k}_{\mathrm{X}}\right|>\frac{\omega}{\mathrm{v}_{\mathrm{j}}}
\end{array}\right.
$$

Where: $\quad \mathrm{k}_{\mathrm{zj}}=\sqrt{\frac{\omega^{2}}{\mathrm{v}_{\mathrm{j}}^{2}}-\mathrm{k}_{\mathrm{x}}^{2}}$

The reference wave function represented by the formula (13) and (14) are complex numbers, thus they will be expressed in the form of modulus and phases as follows:

$$
\begin{array}{r}
P_{j}(x, z+\Delta z, \omega)=A_{j} \exp \left(i \theta_{j}\right) \\
P_{j+1}(x, z+\Delta z, \omega)=A_{j+1} \exp \left(i \theta_{j+1}\right)
\end{array}
$$

Then, using linear interpolation to determine the actual wave function:

$$
\begin{gathered}
\mathrm{P}(\mathrm{x}, \mathrm{z}+\Delta \mathrm{z}, \omega) \approx \mathrm{LI}\left(\mathrm{P}_{\mathrm{j}}(\mathrm{x}, \mathrm{z}+\Delta \mathrm{z}, \omega), \mathrm{P}_{\mathrm{j}+1}(\mathrm{x}, \mathrm{z}+\Delta \mathrm{z}, \omega)\right) \\
\mathrm{A}=\frac{\mathrm{A}_{\mathrm{j}}\left(\mathrm{v}_{\mathrm{j}+1}-\mathrm{v}\right)+\mathrm{A}_{\mathrm{j}+1}\left(\mathrm{v}-\mathrm{v}_{\mathrm{j}}\right)}{\mathrm{v}_{\mathrm{j}+1}-\mathrm{v}_{\mathrm{j}}} \\
\theta=\frac{\theta_{j}\left(\mathrm{v}_{\mathrm{j}+1}-\mathrm{v}\right)+\theta_{\mathrm{j}+1}\left(\mathrm{v}-\mathrm{v}_{\mathrm{j}}\right)}{\mathrm{v}_{\mathrm{j}+1}-\mathrm{v}_{\mathrm{j}}}
\end{gathered}
$$

The wave field need to be found is:

$$
\mathrm{P}(\mathrm{x}, \mathrm{z}+\Delta \mathrm{z}, \omega)=\mathrm{A} \exp (\mathrm{i} \theta)
$$

\section{Trang 76}


Do those calculation steps for each point on the coordinate then solving for all $\omega$ values to obtain the wave field at $\mathrm{t}=0$ :

$\mathrm{P}(\mathrm{x}, \mathrm{z}+\Delta \mathrm{z}, \mathrm{t}=0)=\sum_{\omega} \mathrm{P}(\mathrm{x}, \mathrm{z}+\Delta \mathrm{z}, \omega)$

Hence, the phase shift plus interpolation migration was completed in transforming the reflected signal in the recorded data into the image of the subsurface reflectors.

\section{Root Mean Square Velocity and Interval Velocity}

There are two kinds of velocities usually used in migration methods: root mean square (RMS) velocity $\mathrm{V}_{\mathrm{rms}}$ and interval velocity $\mathrm{v}_{\text {int }}$.

RMS velocity, which is used in $\mathrm{F}-\mathrm{K}$, finite difference and Kirchhoff time migration, is the average velocity taken into account by considering the influence of the upper layer's instantaneous velocity.

The formula used to compute the RMS velocity [4]:

$$
\mathrm{v}_{\mathrm{rms}}(\mathrm{z})=\frac{1}{\tau} \int_{0}^{\tau} \mathrm{v}_{\text {ins }}^{2}(\tau) \mathrm{d} \tau
$$

Interval velocity $v_{\text {int }}$ is obtained for each range $\Delta t$ and $\Delta z$, in the data processing; it is often used nearly as the instantaneous velocity of one layer, excluding the impact of above layers. Interval velocity is used in PSPI migration.

The formula used to compute the interval velocity $[3,4]$ :

$$
\mathrm{v}_{\text {int }}=\frac{\mathrm{z}_{2}-\mathrm{z}_{1}}{\tau_{2}-\tau_{1}}
$$

The relevant formula of interval velocity and RMS velocity [4]:

$$
\tilde{v}_{\text {int }}=\sqrt{\frac{\mathrm{v}_{\mathrm{rms} 2}^{2} \tau_{2}-\mathrm{v}_{\mathrm{rms} 1}^{2} \tau_{1}}{\tau_{2}-\tau_{1}}}
$$

$$
v_{\text {rms }}=\sqrt{\frac{v_{\text {int } 1}^{2} t_{2}+v_{\text {int } 2}^{2} t_{1}}{t_{1}+t_{2}}}
$$

\section{Minimum Entropy Method}

In GPR method, it is difficult to determine accurately the velocity of the subsurface by distinguishing on migrated sections with nearly velocities value. Therefore, the minimum Entropy method [5] is used to pick the velocity which has the smallest error.

Entropy is a measure of the interference of signal in a particular signal section. The less interfering signal that the section has, the more exactly location and size of object that this section reflects. In other words, the migrated section with the exactly velocity up to the peak of the anomalous will have the minimum entropy value.

The formula used to compute Entropy [6]:

$$
\operatorname{En}(\mathrm{P})=\frac{\left[\sum_{\mathrm{m}}^{\mathrm{M}} \sum_{\mathrm{n}}^{\mathrm{N}} \mathrm{P}^{2}(\mathrm{~m}, \mathrm{n})\right]^{2}}{\sum_{\mathrm{m}}^{\mathrm{M}} \sum_{\mathrm{n}}^{\mathrm{N}} \mathrm{P}^{4}(\mathrm{~m}, \mathrm{n})}
$$

Where $\operatorname{En}(\mathrm{P})$ is the entropy value of the wave field's matrix $\mathrm{P}$. The matrix's size is $(\mathrm{M} \times \mathrm{N})$.

\section{RESULTS}

\section{Model Data}

Fig. 1 shows two-layer model simulates a subsurface consisting of two buried objects: circular tube and a square concrete culvert. The survey frequency is $700 \mathrm{MHz}$. The model consists of two layers:

Layer 1: at the depth from $\mathrm{z}=0 \mathrm{~m}$ to $\mathrm{z}=0.5 \mathrm{~m}$, propagation velocity $\mathrm{v}_{1}=0.12239 \mathrm{~m} / \mathrm{ns}$.

Layer 2: at the depth from $\mathrm{z}=0.5 \mathrm{~m}$ to the rest, $\mathrm{v}_{2}=0.074949 \mathrm{~m} / \mathrm{ns}$, this layer has a circular tube with the diameter is $\Phi=0.25 \mathrm{~m}$, the center coordinate is at $(\mathrm{x}=3 \mathrm{~m}, \mathrm{z}=1 \mathrm{~m}), \mathrm{v}=0.0027123 \mathrm{~m} / \mathrm{hs}$, and a square concrete culvert, side $\mathrm{d}=1 \mathrm{~m}$, center coordinate is at $(\mathrm{x}=5.5 \mathrm{~m}, \mathrm{z}=1.5 \mathrm{~m}), \mathrm{v}=0.12197 \mathrm{~m} / \mathrm{ns}$. 


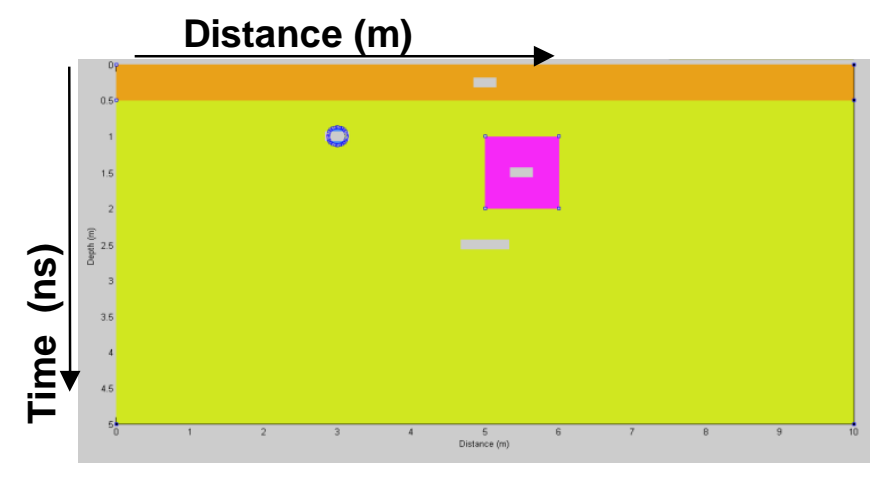

Two-layer Model (Distance-Depth).

Fig. 1. A two-layer model

As been seen in the GPR section (Figure 2), the square concrete culvert's signal is a clearly horizontal line at $x=5 \mathrm{~m} \rightarrow \mathrm{x}=6 \mathrm{~m}, \mathrm{t}=23 \mathrm{~ns}$, with two half of

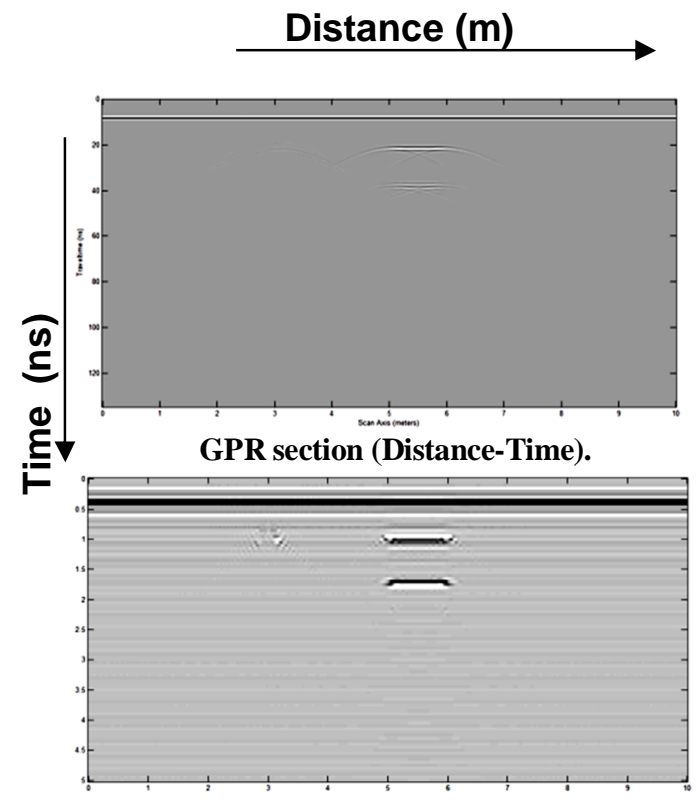

The result of PSPI migration with $\mathrm{v}=0.075 \mathrm{~m} / \mathrm{ns}$ (Distance-Depth). hyperbole at two end points. The circular tube's signal is a very faint beam of hyperbolas with the peak at $\mathrm{x}=3 \mathrm{~m}, \mathrm{t}=23 \mathrm{~ns}$.

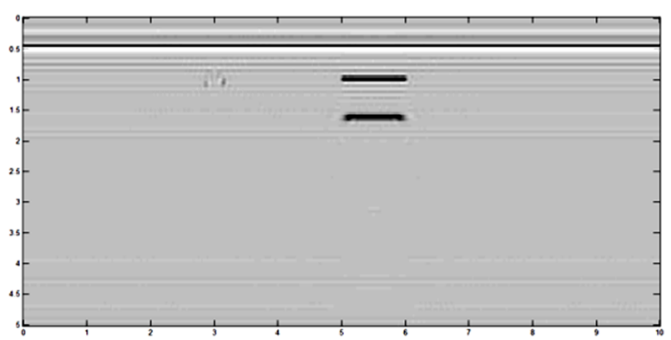

Fig 2. The result of PSPI migration with interval velocities (Distance-Depth) 


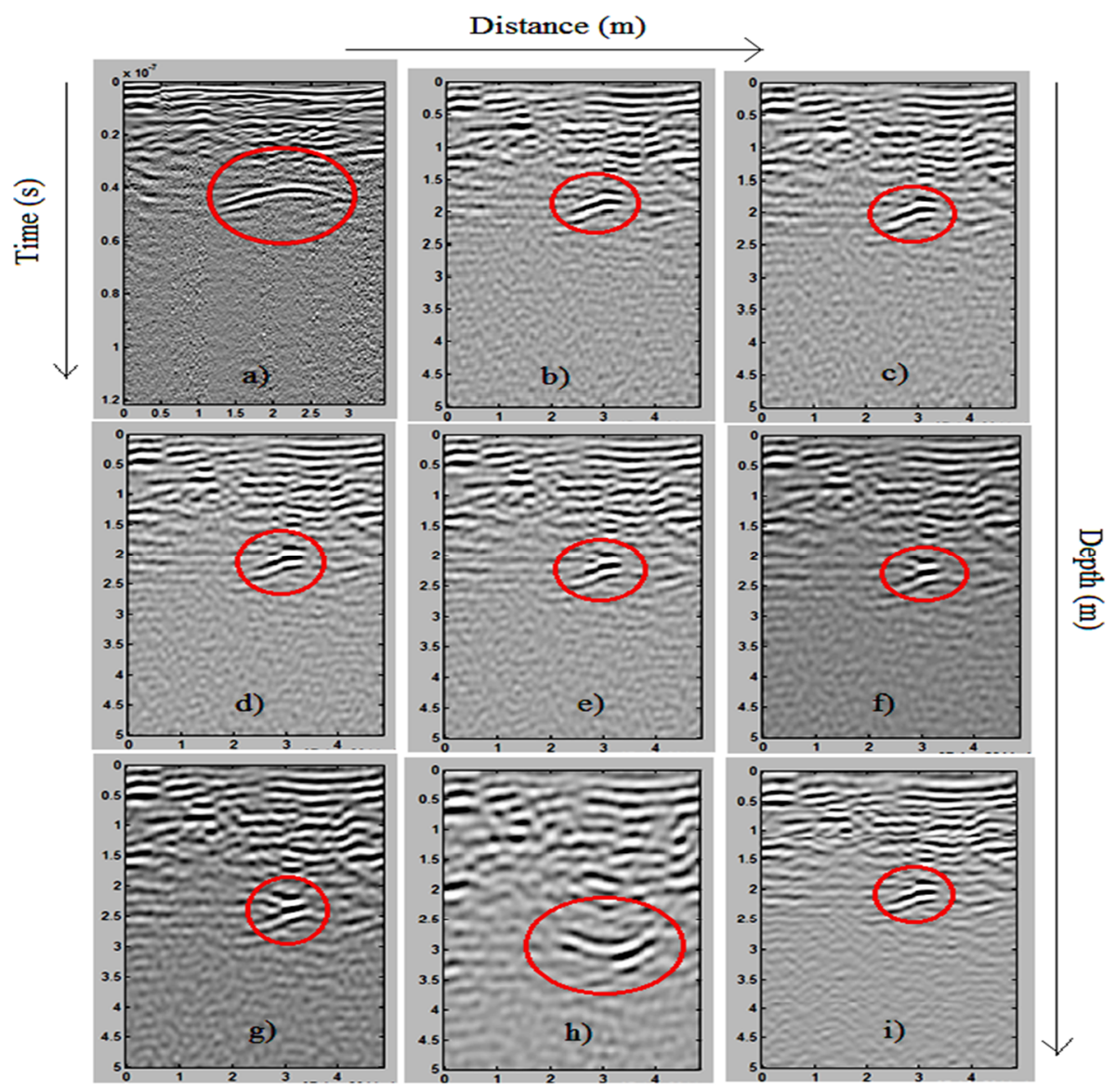

Fig.3. a) GPR section before migration step (distance-time); The results respected to the velocities (distance-depth): b) $v=$ $0,090 \mathrm{~m} / \mathrm{hs}$; c) $0,095 \mathrm{~m} / \mathrm{hs}$; d) $0,100 \mathrm{~m} / \mathrm{ns}$; e) $0,105 \mathrm{~m} / \mathrm{hs}$; f) $0,110 \mathrm{~m} / \mathrm{hs}$; g) $0.115 \mathrm{~m} / \mathrm{hs}$; h) $0.150 \mathrm{~m} / \mathrm{hs}$; i) interval velocities

After being applied PSPI migration with velocities: $0.075 \mathrm{~m} / \mathrm{ns}, 0.095 \mathrm{~m} / \mathrm{ns}, 0.122 \mathrm{~m} / \mathrm{ns}$ and interval velocity of both layers, the results were received as (Fig. 3). Among of those velocities, as calculated from equation (26), $\mathrm{v}=0.095 \mathrm{~m} / \mathrm{ns}$ is RMS velocity up to the top of the anomalous.

Studying those migrated sections, some nocticeable comments could be given:

The circular tube's signal: When velocities being smaller than the RMS velocity (up to the peak of the anomalous) are used in migration, the hyperbolic signal is curved down (Fig. 3), while velocities being greater than the RMS velocity are used, the hyperbola is curved up (Fig. 4). However, when the RMS velocity or interval velocity is used in migration, the signal is put on the shape and the depth corresponding to the shape and the depth of the burried object.

The square concrete culvert's signal: Similar to signals of the circular tube, when velocities which are different from the RMS velocity up to the top of anomalous, are applied to migration step, the signal does not reflect the size and the depth of the object. Only when the RMS velocity or interval velocity is used, the signal's shape can help to determine the size and the depth of the upper part of burried object.

Although both RMS and interval velocities give good results, the migrated section using interval 
velocity is always clearer and have less noise than the migrated section using RMS velocity. More importantly, migration with interval velocities can give the result reflecting exactly the depth of the layers above the anomalous, whereas migration with RMS velocity shows only the depth of surveyed object.

\section{Real Data}

The real data was recorded at Binh Tien Street, District 6, Ho Chi Minh City, Vietnam. The survey frequency is $250 \mathrm{MHz}$.

GPR section of Binh Tien data (Fig. 3a) has a reverse polarized hyperbolic signal, with the peak at $\mathrm{x}=2.25 \mathrm{~m}, \mathrm{t}=40 \mathrm{~ns}$. Executing PSPI migration with velocities $0.090 \mathrm{~m} / \mathrm{hs}, 0.095 \mathrm{~m} / \mathrm{ns}, 0.100 \mathrm{~m} / \mathrm{hs}, 0.105$ $\mathrm{m} / \mathrm{ns}, 0.110 \mathrm{~m} / \mathrm{ns}, 0.115 \mathrm{~m} / \mathrm{ns}, 0.150 \mathrm{~m} / \mathrm{ns}$, the results obtained were showed in Figure 3b, 3c, 3d, 3e, 3f, 3g, $3 \mathrm{~h}$, respectively.

When the original GPR section is executed by PSPI migration with $\mathrm{v}=0.09 \mathrm{~m} / \mathrm{ns}$, the hyperbolic signal is curved down (Fig. 3a), whereas it is migrated with $\mathrm{v}=0.150 \mathrm{~m} / \mathrm{ns}$, the hyperbolic signal is curved up (Fig. 3h). Both these velocities are not the RMS velocity of the subsurface.

When the GPR section is migrated with the velocity range between $0.095 \mathrm{~m} / \mathrm{ns}$ and $0.115 \mathrm{~m} / \mathrm{ns}$, the migrated signal's shape are similar, so it is really difficult to determine the accurate RMS velocity only basing on those sections (Fig. 3b, 3c, 3d, 3e, 3f, 3g). Therefore, to approximate the propagation velocity, the entropy graph of migrated sections should be used to pick the minimum entropy value.

Plotting the Entropy graph of migrated sections with the velocity range of $0.08 \mathrm{~m} / \mathrm{ns}$ to $0.120 \mathrm{~m} / \mathrm{ns}$, the result is obtained (Fig. 4). According to Fig. 4, it could be deduced that the migrated section with $\mathrm{v}=$ $0.100 \mathrm{~m} / \mathrm{ns}(3 \mathrm{~d})$ has the minimum entropy, it means that $\mathrm{v}=0.100 \mathrm{~m} / \mathrm{ns}$ is the RMS velocity up to the top of the anomalous.

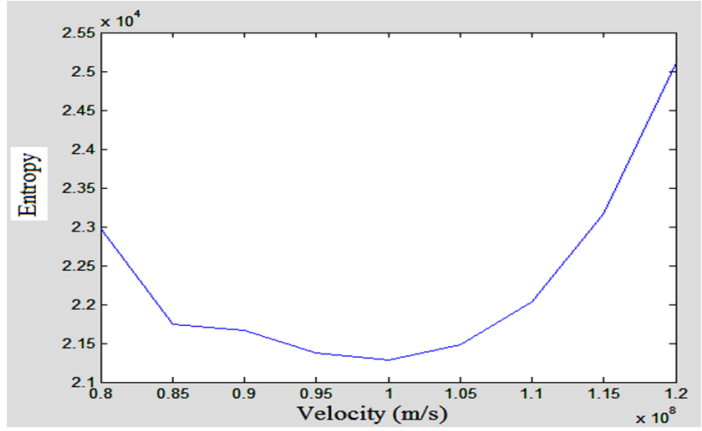

Fig. 4. Graph of Entropy

Combining with priori information, the upper layer of the subsurface is a $0.3 \mathrm{~m}$ thick layer of asphalt with the propagation velocity is $\mathrm{v}=0.14$ $\mathrm{m} / \mathrm{ns}$, which also is the interval velocity of asphalt layer. Substituting the RMS velocity ( $\mathrm{v}=0.100 \mathrm{~m} / \mathrm{ns}$ ) and the interval velocity of asphalt layer into formula (25), the interval velocity of the layer containing the anomalous could be computed as $0.0943 \mathrm{~m} / \mathrm{ns}$.

Thanks to the two interval velocities of the asphalt layer and the layer containing anomalous, the interval velocity model was built as Fig. 5. Executing PSPI migration with this interval velocity model, the result is yielded as Fig. 3i. This migrated section and the migrated section with RMS velocity (Fig. 3d) have the similarity about the signal's aperture and location. The Entropy value of the migrated section using interval velocity model is also smaller than the Entropy value of RMS velocity migrated section $\left(2.0582 \times 10^{4}<2.1283 \times 10^{4}\right)$.

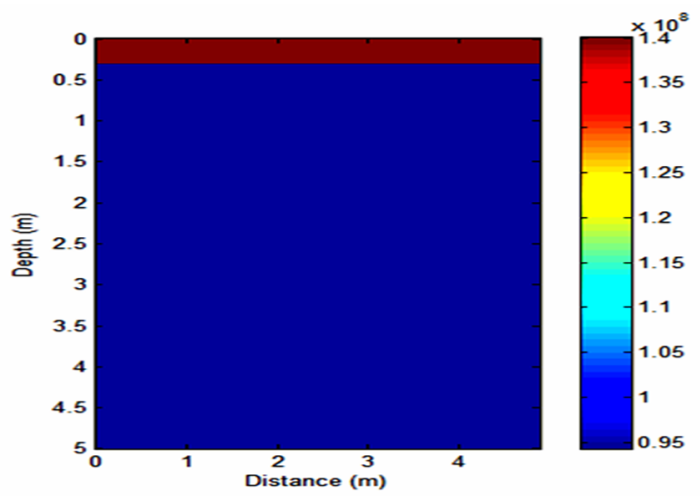

Fig. 5. The interval velocity model

\section{Trang 80}


Therefore, it could be concluded about the anomalous that: thE object has the point size, locates at $(\mathrm{z}=1.9 \mathrm{~m}, \mathrm{x}=3.1 \mathrm{~m})$, the interval velocity of the layer containing object is $0.0943 \mathrm{~m} / \mathrm{ns}$, RMS velocity up to the peak of the object is $0.100 \mathrm{~m} / \mathrm{ns}$.

\section{CONCLUSION}

The application of PSPI migration to interpreting GPR data has advantages and disadvantages as follows:

The migrated section directly reflects the depth of the peak of objects without having to add a calculation suchas FD time migration or Kirchhoff time migration. Besides, PSPI migration can use both interval and RMS velocity; therefore making comparison between two kind of migrated sections could offer more information about the layered structure of the subsurface.

However, PSPI method cannot determine the interval velocity in layered subsurface without priori information. In addition, this method has not given the size and position on the lower part of objects because the variation of velocity field has not been considered.

This research should be expanded in the way of combining many kinds of migration methods, gathering priori information and computing the entropy value in order to determine both RMS and interval velocity, then predict the position, depth and size of the whole anomalous and the layered structure of the subsurface. 


\section{Xác định vận tốc trong thăm dò điện tử tần số cao bằng dịch chuyển dời pha nội suy tuyến tính}

- Nguyễn Thành Vấn

- Lê Hoàng Kim

- Đặng Hoài Trung

- Nguyễn Văn Thuận

Trường Đại học Khoa học Tự nhiên, ĐHQG-HCM

\section{TÓM TẮT}

Dịch chuyển dời pha nội suy tuyến tính (Phase Shift Plus Interpolation migration - PSPI migration) là một trong nhũng phưong pháp được sủ dụng rất phổ biến, không chỉ trong xử lý dũ liệu địa chấn, mà còn trong xử lý tài liệu thăm dò điện tù tần số cao (Radar xuyên đất: GPR). Dựa vào sụ tuoong úng trong lý thuyết lan truyền sóng co học và sóng điện tù̀ mà các phuoong pháp dịch chuyển địa chấn có thể đuợc biến đổi phù hợp để áp dụng vào xư lý tài liệu GPR nhu một công cu tính vận tốc truyền sóng của môi truờng, uớc luợng độ sâu, hình dạng và kích thuớc dị vật. Có hai loại vận tốc thường được dùng trong dịch chuyển: vận tốc căn quân phuơng (RMS) -

sủ dụng trong các loại dịch chuyển $F-K$, dịch chuyển sai phân hũu hạn, dịch chuyển Kirchhoff, và vận tốc khoảng (interval) được sủ dụng trong dịch chuyển PSPI. Vận tốc RMS là vận tốc trung bình được tính tù vận tốc thực của các phân lớp nằm bên trên điểm khảo sát, trong khi vận tốc khoảng chỉ phản ánh vận tốc của riêng phân lớp chúa điểm khảo sát. Bài viết này trình bày cách thức áp dụng dịch chuyển PSPI vào xủ lý dũ liệu GPR, có kèm theo kết quả xủ lý dũ liệu mô hình và dũ liệu thưc tế. Bên cạnh đó, việc kết hợp sủ dụng hai loại vận tốc RMS và vận tốc khoảng vào các bước xử lý cũng được đưa ra phân tích nhằm thu được kết quả tốt nhất.

Tù khóa: ra đa xuyên đất, dịch chuyển PSPI, vận tốc RMS, vận tốc khoảng

\section{REFERENCES}

[1]. N.T. Vấn, N.V. Giảng, L.V.A. Cường, Đ.H. Trung, V.M. Triết. Kirchhoff migration for specifying velocity model in ground penetrating radar method, International conference on Ground Penetrating Radar (GPR), 419 - 424 (2012).

[2]. J. Gazdag, P. Sguazzero. Migration of seismic data by phase shift plus interpolation, Geophysics, 49, No. 2. pp. 124-131 (1984).

[3]. Q. Baolin, C. B. John. Choosing reference velocities for PSPI migration, CREWES Research Report, 21 (2009).

[4]. F. Gary, Margrave. Numerical Methods of exploration seismology with algorithms in MATLAB, Department of Geology and Geophysics, the University of Calgary, Canada, 30-38 (2001)

[5]. F. Daniel, P. Stephen. an entropy-based propagation speed estimationmethod for nearfield subsurface radar imaging. EURASIP Journal on Advances in Signal Processing, 2010, Article ID 636458, 13 (2010).

[6]. X. Xu, L.M. Eric. Entropy optimized contrast stretch to enhance remote sensing imagery, pattern recognition, Proceedings, 16th International Conference, 3, 915-918 (2002).

\section{Trang 82}

